\title{
Retraction Note to: Functionalization of titanium based metallic biomaterials for implant applications
}

\author{
Rahul Bhola $\cdot$ Fengyun Su • Catherine E. Krull
}

Published online: 8 November 2011

(C) Springer Science+Business Media, LLC 2011

Retraction to: J Mater Sci: Mater Med (2011)

22:1147-1159

DOI 10.1007/s10856-011-4305-8

The Editors have determined that this article should be retracted due to plagiarism.

Serena Best and Josep A. Planell

Editors-in-Chief,

Journal of Material Science: Materials in Medicine

The online version of the original article can be found under doi: 10.1007/s10856-011-4305-8.

R. Bhola $(\varangle) \cdot$ F. Su · C. E. Krull

Department of Biologic and Material Sciences, School

of Dentistry, University of Michigan, Ann Arbor,

MI 48109, USA

e-mail: bholar@umich.edu

C. E. Krull

e-mail: krullc@umich.edu 